\title{
Development and characterization of sustainable lightweight geopolymer composites
}

\section{(Desenvolvimento e caracterização de compósitos geopoliméricos leves e sustentáveis)}

\author{
H.M.Khater ${ }^{\text {* }}$ \\ ${ }^{1}$ Housing and Building National Research Center, 87 El-Tahrir St., Dokki, Giza, P.O. Box 11511, Cairo, Egypt
}

\begin{abstract}
Production of lightweight building materials attract the attention of the scientists worldwide with the need for reducing the structure deadweight, provide better thermal insulation for buildings, and cost less to transport. The current work focused on the production of lightweight geopolymer composites by the incorporation of aluminum powder and aluminum slag in various ratios for water-cooled slag/kaolinite sand composite; the activators used were $6 \%$ of equal ratio from sodium hydroxide and sodium silicate. The properties of the produced lightweight geopolymer composites were studied by measurement of compressive strength, bulk density, water absorption, FTIR, XRD and SEM imaging. Results showed the enhancement for both physicomechanical and microstructural characteristics with using aluminum powder and aluminum slag forming lightweight composites with densities below $2.15 \mathrm{~g} / \mathrm{cm}^{3}$ depending on the studied mix composition.
\end{abstract}

Keywords: lightweight, geopolymer, activation, aluminum, slag.

\section{Resumo}

A produção de materiais de construção leves atrai a atenção dos cientistas em todo o mundo com a necessidade de reduzir o peso morto das estruturas, fornecer melhor isolamento térmico para edifícios e ter menor custo de transporte. O presente trabalho centrou na produção de compósitos geopoliméricos leves pela incorporação de pó de alumínio e escória de alumínio em várias proporções para o compósito de escória resfriada a águalareia de caulinita; os ativadores utilizados foram $6 \%$ de igual proporção de hidróxido de sódio e silicato de sódio. As propriedades dos compósitos geopoliméricos leves produzidos foram estudadas pela medição da resistência à compressão, densidade aparente, absorção de água, FTIR, DRX e MEV. Os resultados mostraram que as características físico-mecânicas e microestruturais aumentaram com a utilização de pó de alumínio e escória de alumínio, formando compósitos leves com densidades abaixo de $2,15 \mathrm{~g} / \mathrm{cm}^{3}$, dependendo da composição da mistura estudada.

Palavras-chave: material leve, geopolímero, ativação, alumínio, escória.

\section{INTRODUCTION}

Today, the need for the production of new ecofriendly building materials from each country's natural resources and/ or waste by-products increased vastly with the increasing general awareness concerning the environment which led to a growing concern about the waste generation and the realization that such materials must be treated, eliminated or re-used. Rising consumption and the concomitant increase in industrial production has occasioned both a rapid decline in natural resources and generation of large volumes of waste or by-products [1]. Recent researches into the economically viable re-use of wastes have given rise to different proposals,

*hkhater4@hbrc.edu.eg

(D) https://orcid.org/0000-0002-9832-5895 including the possibility of its inclusion in building materials $[2,3]$. Alkali-activated materials, commonly known as geopolymer if their resources are from nature geological origins rich in silicon and aluminum, whilst if their resource from industrial by-products rich in alumina and silica oxides such as coal fly ash, silica fume and granulated blast furnace slag can be considered as alkali-activated materials which is the major category, whilst geopolymers can be considered a subset of this mother set as coincide with the pioneer scientists Davidovits in 1970s [4, 5]. The basic binding phase in geopolymers is an amorphous aluminosilicate gel that consists of a three-dimensional framework of $\mathrm{SiO}_{4}$ and $\mathrm{AlO}_{4}$ tetrahedra linked by corner-shared $\mathrm{O}$ atoms [6-8]. Geopolymer binders exhibit improved properties compared to traditional binding materials although the most important is their low manufacturing energy consumption and low $\mathrm{CO}_{2}$ 
emission $[9,10]$, which can be sorted as a 'green material' [11]. The importance of green materials increased also vastly with the increased ability for producing lightweight building materials in construction sector that can insulate heat and sound, where traditionally, ordinary Portland cement (OPC) has been used as the binder for concrete [12-14], which exhibits high thermal transmission and can be responsible for about $7 \%$ of the $\mathrm{CO}_{2}$ emission worldwide.

The development of lightweight building materials with good mechanical properties can reduce the deadweight of structures, provide better thermal insulation for buildings, and cost less to transport and erect when prefabricated structural components are made in factory, whereas using lightweight aggregates is one of the most commonly known ways for making lightweight building materials $[15,16]$. The use of lower density concrete is beneficial in terms of structural load-bearing, and acoustic and thermal insulation. The density can be reduced by replacing part of the solids by air voids or lightweight aggregates and several approaches exist for this objective. In the method known as no-fines concrete, the fine aggregate is omitted, whereas in the called lightweight concretes, the normal aggregates are replaced by lightweight ones to reduce the density. If air voids are introduced into the cement paste to reduce its density, the concrete is known as cellular, aerated, or foamed concrete $[17,18]$, which can reduce the quantity of raw material (sand, cement and lime) up to $30 \%$, which knocks down the cost of building materials. There are many types of material that can be suitable for lightweight thermal insulation and fall under the following basic materials and composites [19,20]: 1) inorganic materials: fibrous materials such as glass, rock, and slag wool, fly ash; cellular materials such as calcium silicate, bonded perlite, vermiculite, ceramic products and geopolymer; 2) organic materials: fibrous materials such as cellulose, cotton, wood, pulp, cane, or synthetic fibers; cellular materials such as cork, foamed rubber, polystyrene, polyethylene, polyurethane, polyisocyanurate and other polymers. Various routes are available to suit lightweight production, one of such chemicals to generate gas within the mixture is metallic aluminum powder, which is very reactive in alkaline environments, such as calcium hydroxide or alkaline hydroxides; the aluminum dissolves as aluminate $\left(\mathrm{Al}_{2} \mathrm{O}^{-}\right)$and $\mathrm{H}_{2}$ gas is liberated and trapped within the cementitious paste or mortar, expanding and increasing the volume. In order to prevent the escape of the gas, the paste must have a proper consistency and fast setting times, according to the following reaction [21, 22]:

$$
4 \mathrm{Al}+\mathrm{OH}^{-}+\mathrm{H}_{2} \mathrm{O} \rightarrow 2 \mathrm{Al}_{2} \mathrm{O}^{-}+3 / 2 \mathrm{H}_{2}
$$

Another low-cost material for lightweight production and available in large quantities is aluminum slag (dross) which incorporates air into the mixture and can be used in the manufacturing of building blocks (bricks), pre-molded panels, subfloors and other kinds of surfaces. Approximately, up to 4 million tons of white dross and more than a million tons of black dross are reported throughout the world each year, and around $95 \%$ of this material is landfilled $[23,24]$. This material also can be used as raw materials in cement production industry as proved by Puertas et al. [25] as well as Pereira et al. [26] who explored partial replacement of aluminum dross to cement mortar in certain limits to obtain environmental and economic advantages. Others recommended the usage of aluminum dross as filler in concrete bricks and non-aerated concrete [24]. The objective of this contribution is to investigate the effect of aluminum powder and aluminum slag into the geopolymer composites as gas liberating agent and producing lightweight geopolymer structures. The other target is to study the effect of added materials on the hardened composites by monitoring their impacts on physicomechanical and microstructural characteristics. X-ray diffraction and FTIR spectroscopy were used for investigation of the resulted composite structure.

\section{EXPERIMENTAL PROCEDURES}

Materials: materials used were ground granulated blast furnace slag (GGBFS) sourced from Iron and Steel FactoryHelwan, Egypt, and kaolinite sand material brought from the Middle East for Mining Investment Co., Egypt. Materials used for the production of lightweight composites were: i) aluminum slag procured from Nagh Hammadi Factory for aluminum production, Egypt, generated from the recovery of aluminum through scrap recycling, where a great quantity of oxide layer formed on the surface of molten metal was removed from the melt to refine the quality of the final product; and ii) aluminum powder (Adwic Chemicals, Egypt, 94\% of purity)

Table I - Chemical composition of starting materials (mass \%). [Tabela I - Composição química dos materiais de partida (\% em massa).]

\begin{tabular}{cccc}
\hline Material & $\begin{array}{c}\text { Kaolinitic } \\
\text { sand }\end{array}$ & GGBFS & $\begin{array}{c}\text { Alumina } \\
\text { slag }\end{array}$ \\
\hline $\mathrm{SiO}_{2}$ & 64.50 & 36.67 & 14.52 \\
$\mathrm{Al}_{2} \mathrm{O}_{3}$ & 26.90 & 10.31 & 76.15 \\
$\mathrm{Fe}_{2} \mathrm{O}_{3}$ & 0.28 & 0.50 & 0.60 \\
$\mathrm{CaO}$ & 1.28 & 38.82 & 2.39 \\
$\mathrm{MgO}$ & 0.37 & 1.70 & 3.15 \\
$\mathrm{SO}_{3}$ & 0.34 & 2.17 & 0.19 \\
$\mathrm{~K}_{2} \mathrm{O}$ & 0.07 & 1.03 & 0.36 \\
$\mathrm{Na}_{2} \mathrm{O}$ & 0.11 & 0.48 & 2.37 \\
$\mathrm{TiO}_{2}$ & 1.11 & 0.57 & 0.02 \\
$\mathrm{MnO}_{2}$ & 0.01 & 4.04 & 0.00 \\
$\mathrm{P}_{2} \mathrm{O}_{5}$ & 0.22 & 0.04 & 0.01 \\
$\mathrm{Cl}^{-}$ & 0.07 & 0.05 & - \\
$\mathrm{SrO}$ & - & 0.18 & - \\
$\mathrm{BaO}$ & - & 3.28 & - \\
$\mathrm{L.O} . \mathrm{I}$. & 4.34 & 0.12 & - \\
$\mathrm{Total}$ & 99.60 & 99.96 & 99.75 \\
\hline
\end{tabular}

GGBFS - ground granulated blast furnace slag. 


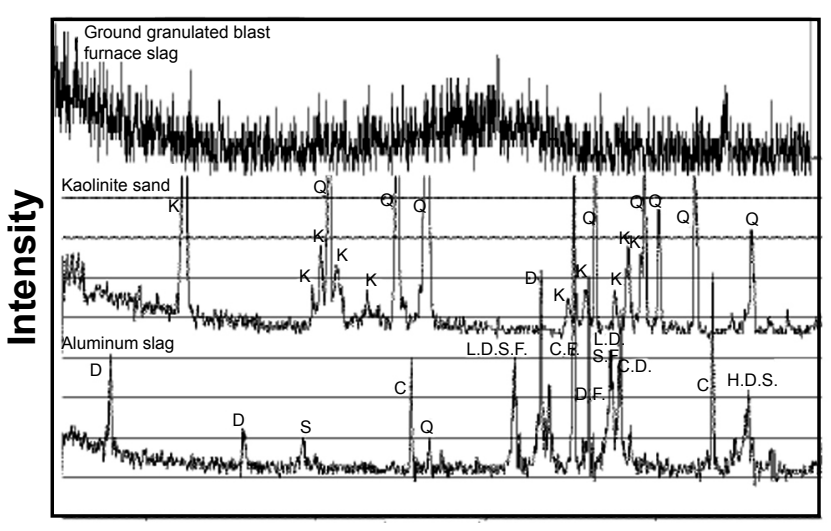

\section{$2 \theta$ (degree)}

Figure 1: X-ray diffraction patterns of starting raw materials: K-kaolinite; Q-quartz; D-diaoyudaoite $\left(\mathrm{Na}_{1.22} \mathrm{Al}_{11} \mathrm{O}_{17.11}\right)$; S-spinel $\left(\mathrm{Mg}_{0.35} \mathrm{Al}_{0.65}\right) \mathrm{Al}_{178} \mathrm{O}_{4} ; \quad$ C-corundum $\left(\mathrm{Al}_{2} \mathrm{O}_{3}\right) ;$ L-lime $(\mathrm{CaO})$; F-magnesian fayalite $\left(\mathrm{Mg}_{075} \mathrm{Fe}_{1.10} \mathrm{Mn}_{0.15} \mathrm{SiO}_{4}\right) ; \mathrm{H}$-halite $(\mathrm{NaCl})$.

[Figura 1: Difratogramas de raios $X$ dos materiais de partida.]

used as hydrogen gas liberating materials for geopolymer composites; iii) sodium hydroxide $(\mathrm{NaOH})$ with $99 \%$ purity in the form of pellets used as alkali activators, obtained from Piochem Co., Egypt; and iv) liquid sodium silicate (LSS, $\mathrm{Na}_{2} \mathrm{SiO}_{3} .9 \mathrm{H}_{2} \mathrm{O}$ ) from Fisher Co. consisted of $32 \% \mathrm{SiO}_{2}$ and $17 \% \mathrm{Na}_{2} \mathrm{O}$ with silica modulus $\left(\mathrm{SiO}_{2} / \mathrm{Na}_{2} \mathrm{O}\right)$ equal to 1.88 and density of $1.46 \mathrm{~g} / \mathrm{cm}^{3}$. Chemical compositions of the starting raw materials are shown in Table I, whereas the mineralogical characterization by $\mathrm{X}$-ray diffraction analysis is represented in Fig. 1. Blast furnace slag was an aluminosilicate material and composed with the dominant contents of $\mathrm{SiO}_{2}, \mathrm{CaO}$, $\mathrm{Al}_{2} \mathrm{O}_{3}, \mathrm{Fe}_{2} \mathrm{O}_{3}$, and $\mathrm{MnO}$ (Table I), while its mineralogical structure revealed its amorphous nature. Kaolinite sand had about $27 \%$ aluminum oxide as well as $64.5 \%$ of silicon oxide, in addition to the little amount of calcium and magnesium oxides (Table I); the mineralogical compositions showed that kaolinite sand was composed of about $75 \%$ quartz in addition to $25 \%$ kaolinite (Fig. 1), and also reflected the crystalline nature of aluminum slag where most of its minerals were rich in alumina as diaoyudaoite, fayalite, spinel and corundum.

Geopolymerization and curing: geopolymers were set by mixing raw materials (passing $90 \mu \mathrm{m}$ sieve) of each mixture with the alkaline solution as shown in Table II for $15 \mathrm{~min}$ with an electronic mixer. Aluminum powder was added to the binding material in small ratios from 0.0125 up to $0.075 \%$ with the increment of $0.0125 \%$ of the total weight, whereas aluminum slag was added in the ratio from 1 to $4 \%$ of the total weight. Used aluminum materials mixed well with the total water incorporated and the added activators for the production of foaming materials. All mixes were left to cure undisturbed under ambient temperature for $24 \mathrm{~h}$ and then subjected to curing at $40{ }^{\circ} \mathrm{C}$ and $100 \%$ relative humidity. After the curing regime, specimens were dried at $80{ }^{\circ} \mathrm{C}$ for $24 \mathrm{~h}$ and then subjected to compressive strength measurements; the resulted crushed specimens were subjected to methyl alcohol/acetone method to stop the hydration process [27, 28], followed by drying at $80{ }^{\circ} \mathrm{C}$ for $24 \mathrm{~h}$ and then preserved in a well-tight container until the time of testing.

Methods of characterization: chemical analysis of the started raw materials was performed using Axios, X-ray fluorescence (WD-XRF) sequential spectrometer (Panalytical). Compressive strength tests were performed according to ASTM-C109 [29] using German Brüf pressing machine. X-ray diffraction (XRD) analysis was carried out using Philips PW3050/60 diffractometer. The microstructure of hardened materials was examined using FEI-SEM Inspect $\mathrm{S}$ equipped with an energy dispersive $\mathrm{X}$-ray (EDX) analyzer. The amorphous structure was traced using Fourier-transform infrared (FTIR) spectrometer using potassium bromide binder, scanning in the range from 400 to $4000 \mathrm{~cm}^{-1}[30,31]$. Water absorption measurements of the specimens were carried out according to ASTM C140 [32] and calculated by:

$$
\text { Absorption }(\%)=[(\mathrm{W} 2-\mathrm{W} 1) / \mathrm{W} 1] .100
$$

where $\mathrm{W} 1$ is the weight of specimen after complete drying at $105^{\circ} \mathrm{C}$ and W2 is the final weight of the surface-dry sample after immersion in water for at least $24 \mathrm{~h}$. The bulk density was calculated according to the Archimedes principle [33, 34]:

$$
\text { Bulk density }=\mathrm{D} /(\mathrm{W}-\mathrm{S})
$$

where D is the weight of dried specimens, $\mathrm{W}$ is the weight of soaked specimen suspended in air, and $\mathrm{S}$ is the weight of suspended specimens in water.

\section{RESULTS AND DISCUSSION}

\section{Effect of aluminum powder}

FTIR spectra of neat geopolymer composite without aluminum powder cured up to 90 days are shown in Fig. 2a. It was noticed a decrease in kaolinite peaks beyond $3600 \mathrm{~cm}^{-1}$ with time as a result of continuous dissolution

Table II - Composition of the geopolymer mixes.

[Tabela II - Composição das misturas geopoliméricas.]

\begin{tabular}{cccccccccccc}
\hline & A0 & A1 & A2 & A3 & A4 & A5 & A6 & AS1 & AS2 & AS3 & AS4 \\
\hline Al-slag (\%) & - & - & - & - & - & - & - & 1 & 2 & 3 & 4 \\
Al powder (\%) & 0 & 0.0125 & 0.0250 & 0.0375 & 0.0500 & 0.0625 & 0.0750 & - & - & - & - \\
Water/binder & 0.25 & 0.25 & 0.25 & 0.25 & 0.25 & 0.25 & 0.25 & 0.225 & 0.250 & 0.275 & 0.288 \\
\hline
\end{tabular}

Each mix contained: water cooled slag (WCS): 50\%; kaolinite sand: $50 \%$; $\mathrm{NaOH}$ : $3 \%$; sodium silicate: $3 \%$. 

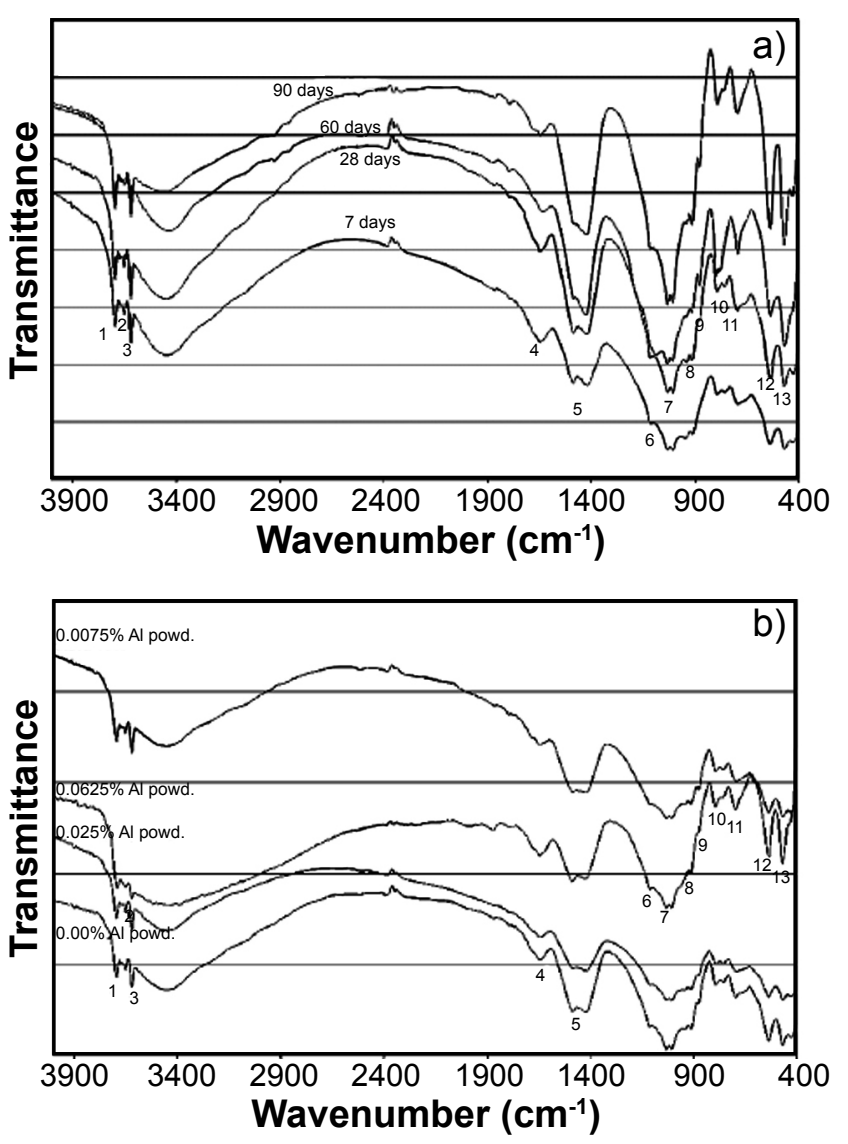

Figure 2: FTIR spectra of: a) control geopolymer composite cured up to 90 days at $40{ }^{\circ} \mathrm{C}$ with $100 \% \mathrm{RH}$; and b) 28 days lightweight geopolymer composite having various doses of aluminum powder. Modes of vibration: 1,2,3: stretching of $\mathrm{O}-\mathrm{H}$ bond for kaolin; 4 : bending of $\mathrm{HOH}$; 5 : stretching of $\mathrm{CO}_{2} ; 6$ : asymmetric stretching $\mathrm{Si}-$ $\mathrm{O}-\mathrm{Si}$; 7: asymmetric stretching T-O-Si; 8: symmetric stretching of Al-OH; 9: symmetric stretching of $\mathrm{CO}_{2}$; 10: symmetric stretching Al-O-Si; 11: symmetric stretching $\mathrm{Si}-\mathrm{O}-\mathrm{Si} ; 12,13$ : bending $\mathrm{Si}-\mathrm{O}-\mathrm{Si}$ and $\mathrm{O}-\mathrm{Si}-\mathrm{O}$.

[Figura 2: Espectros de FTIR de: a) compósito geopolimérico de controle curado até 90 dias a $40{ }^{\circ} \mathrm{C}$ com $100 \%$ de $\mathrm{HR}$; e b) compósito geopolimérico leve aos 28 dias com vários teores de pó de alumínio. Modos de vibração: 1,2,3: estiramento da ligação $\mathrm{O}$-H do caulim; 4: deformação de $\mathrm{HOH}$; 5: estiramento de $\mathrm{CO}_{2} ; 6$ : estiramento assimétrico $\mathrm{Si}-\mathrm{O}-\mathrm{Si}$; 7: estiramento assimétrico T-O$\mathrm{Si}$; 8: estiramento simétrico de $\mathrm{Al}-\mathrm{OH}$; 9: estiramento simétrico de $\mathrm{CO}_{2}$; 10: estiramento simétrico $\mathrm{Al}-\mathrm{O}-\mathrm{Si} ; 11$ : estiramento simétrico $\mathrm{Si}$-O-Si; 12,13: flexão $\mathrm{Si}-\mathrm{O}$-Si e $\mathrm{O}$-Si-O.]

and polymerization of residual kaolinite forming additional geopolymer constituents leading to an increased reinforcement of the matrix; this was confirmed by an increased intensity of the asymmetric stretching vibration $\mathrm{T}-\mathrm{O}-\mathrm{Si}$ at about $1000 \mathrm{~cm}^{-1}$ where $\mathrm{T}=\mathrm{Si}$ or $\mathrm{Al}$, as a result of the increased geopolymerization and precipitation; this occurred in conjunction with an increased intensity of symmetric stretching vibration Al-O-Si at about $780 \mathrm{~cm}^{-1}$ as well as symmetric stretching vibration $\mathrm{Si}-\mathrm{O}-\mathrm{Si}$ at about $670-685 \mathrm{~cm}^{-1}$. Also, bands close to $460 \mathrm{~cm}^{-1}$ were attributed to angular deformations of $\mathrm{SiO}_{4}$ tetrahedrons (O-Si-O), as well as asymmetric stretching vibration of $\mathrm{Si}-\mathrm{O}-\mathrm{Si}$ (for non-solubilized particles) probably associated with quartz [35]; these results were similar to those obtained in [36]. Stretching vibration for Al-OH at about $910 \mathrm{~cm}^{-1}$ resulted from free unreacted aluminum species also decreased with time as unreacted free alumina was exposed to dissolution and polymerization over time [37]. It was noticed a shift in the wavenumber of main asymmetric band to the right with an increased intensity in the time reflecting the increase of vitreous content which agreed with the observation that the incorporation of kaolinite sand retards polymerization reaction in the very early period of reaction [38, 39], while at later ages an increased dissolution of $\mathrm{Al}$ from kaolinite sand leads to an enhanced polymerization and modifies the chemistry of the Si-O-T bonds (giving a decrease in the wavenumber) [38, 39].

On investigating the effect of addition of various ratios of aluminum powder up to $0.075 \%$ cured at 28 days on FTIR spectra (Fig. 2b), it was observed a slight decrease in the main asymmetric band (T-O-Si) adding $0.025 \%$ aluminum as a result of alteration in the $\mathrm{Si} / \mathrm{Al}$ ratio; however a gradual increase in the band intensity with shifting to right was recognized with increasing the aluminum powder up to $0.0625 \%$ where the added aluminum resulted in enhancing the degree of polymerization by the effect of seeded nucleation, which resulted in the formation of nucleation sites for geopolymer formation and precipitation which positively enhanced the resulted geopolymer structure [40]; this shift also indicated the formation of a new product (amorphous aluminosilicate gel phase) [30]. However, further increase in the aluminum powder resulted in an increase of liberated hydrogen gas as mentioned previously by reacting with alkali; this gas resulted in an increased porosity as well as hindered interaction between binding materials leading to a lowering in intensity of the main asymmetric band with increased intensity of kaolinite bands reflecting low dissolution rate of the kaolinite precursor as compared with the lower aluminum powder ratio; additionally carbonate bands at about 1440 and $870 \mathrm{~cm}^{-1}$ had increased intensity with aluminum powder up to $0.0625 \%$ then decreased using $0.075 \%$ aluminum powder, which can be linked by the behavior of asymmetric vibration of T-O-Si as the hydrogen gas hindered the interaction between the reacting particles leading to the lowering of the carbonation rate of geopolymer composites with higher aluminum powder ratio.

Fig. 3 shows the XRD patterns of 28 days alkaliactivated geopolymer composites incorporating various ratios of aluminum powder, where a gradual increase in the amorphous geopolymer constituents with aluminum powder up to $0.0625 \%$ as represented by increased broadness with peak distortion between 20 and $35^{\circ} 2 \theta$ characterizing glassy phase of geopolymer constituents; however, this broadness decreased with further aluminum increase as well as using lower doses, the same trends as shown by the FTIR spectra. The increased intensity of amorphous constituents by the formation of new phases was aligned with the increased broadness in the range from 6 to $10^{\circ} 2 \theta$ for aluminosilicate gel, where this increase reflected the increased dissolution 
of geopolymer precursor [41]. Another more likely reason was that the unique conditions in the early stages of seeded geopolymer formation by $\mathrm{Al}$ substitutes may have created an environment where zeolite Na-F was able to be directly synthesized by the hydrothermal treatment of kaolinite or metakaolin at relatively low temperatures $\left(\sim 80{ }^{\circ} \mathrm{C}\right)[40$, 42]. These phases were Al-rich gel, which did not occur in the unseeded system and also explained the formation of zeolite [43]. On further increase in aluminum powder, there was an intense peak for faujasite and zeolite favored the lower geopolymer characteristic as known by its lower branching ability; this was in accordance with [44], where the crystalline zeolite phases are destructive to the consistent distribution of geopolymers.

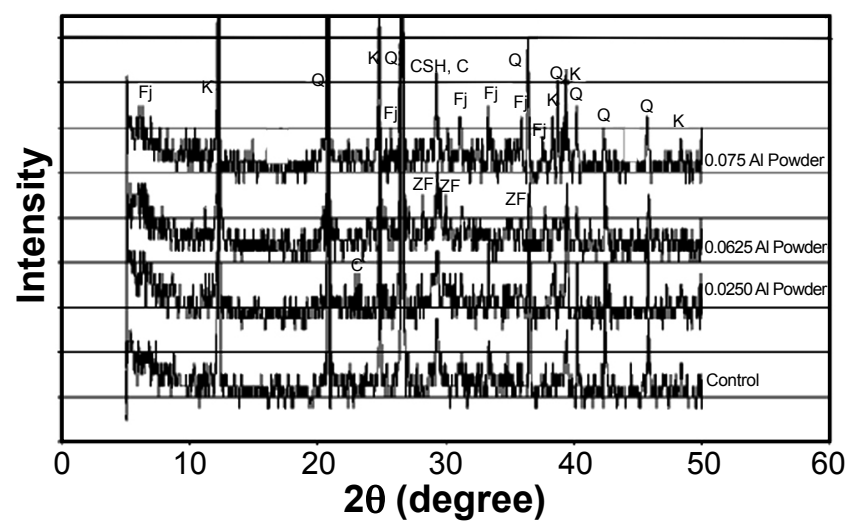

Figure 3: XRD patterns of 28 days lightweight geopolymer composite having various aluminum powder ratios: Q-quartz; K-kaolin; Fj-faujasite; CSH-calcium silicate hydrate; ZF-zeolite Na-F.

[Figura 3: Difratogramas de raios $X$ do compósito geopolimérico leve aos 28 dias com vários teores de pó de alumínio: Q-quartzo; $\mathrm{K}$-caulim; Fj-faujasita; $\mathrm{CSH}$-silicato de cálcio hidratado; $\mathrm{ZF}$ zeólita Na-F.]

The results of compressive strength and absorption as well as bulk density for hardened geopolymer composite incorporated with various ratio of aluminum powder, cured in $100 \%$ relative humidity at $40{ }^{\circ} \mathrm{C}$ up to 90 days are shown in Figs. 4 and 5. The results showed an increase in strength for all mixes along with hydration age as attributed to the continuing pozzolanic reaction as well as the continuous growth of geopolymer chains forming a tightly bound structure. The dissolution of the aluminum powder with its high reactivity in an alkaline environment transformed it into aluminate species and released free hydrogen gas. The aluminate species promoted the reaction by the effect of seeded nucleation as mentioned latter and enhanced propagation as well as precipitation of geopolymer chains, while the liberated gas facilitated the formation of lightweight composites with lower density as compared with common building materials units. There was a sharp strength decrease with the addition of $0.0125 \%$ aluminum, which can be explained from both FTIR and XRD results as the alteration in $\mathrm{Si} / \mathrm{Al}$ ratio that led to a decrease in strength. Increasing the ratio of the added aluminum resulted in a gradual increase in strength, reaching the maximum value at $0.0625 \%$ followed by a rapid decrease with the further aluminum increase. The strength increase can be explained by the increased asymmetric stretching vibration of amorphous glassy geopolymer phases at about $1000 \mathrm{~cm}^{-1}$ where the seeded nucleation effect of the liberated aluminate enhanced the nucleation and geopolymerization of reacting materials, forming zeolite $\mathrm{Na}-\mathrm{F}$ which is known by its ability to strengthen the structure. However, a further increase in the aluminum powder resulted in an extra increase in the liberated hydrogen gas which compensated the activation role of aluminate species by absorption increase and so hindered interaction between the reacting species and so lowered the intensity of the formed geopolymer as well as strength.

It was noticed that the strength values were 214.0, 271.0 and $112.4 \mathrm{kgf} / \mathrm{cm}^{2}$ at 7 days and $239.5,350.0$ and $109.1 \mathrm{kgf} / \mathrm{cm}^{2}$ at 28 days for additions of $0,0.0625$ and $0.075 \%$ aluminum powder, respectively, while the density values were $1.874,2.010$ and $1.599 \mathrm{~g} / \mathrm{cm}^{3}$ at 7 days and $1.886,2.016$ and $1.598 \mathrm{~g} / \mathrm{cm}^{3}$ at 28 days for the same ratios.

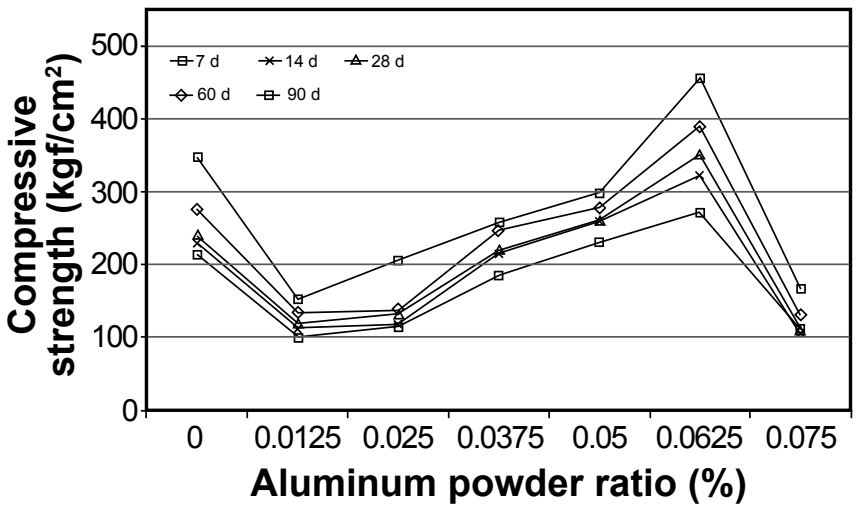

Figure 4: Compressive strength of lightweight geopolymer composite having various ratios of aluminum powder, cured up to 90 days.

[Figura 4: Resistência à compressão do compósito geopolimérico leve com vários teores de pó de alumínio, curado até 90 dias.]

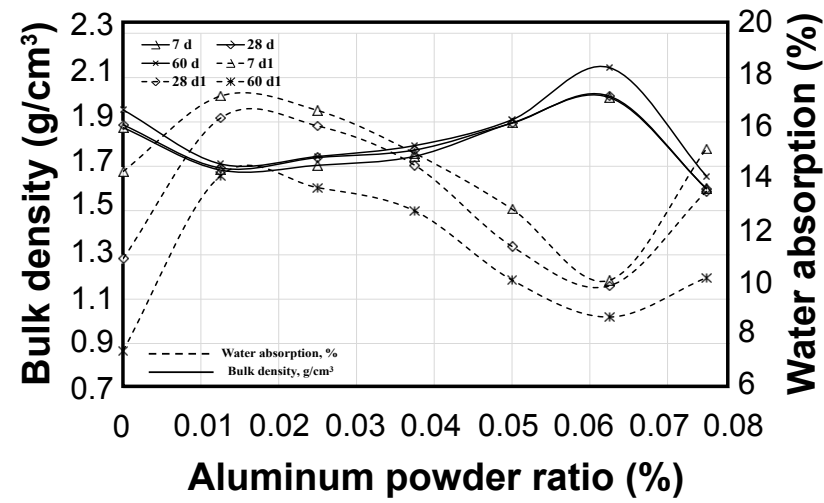

Figure 5: Bulk density and water absorption of lightweight geopolymer composite doped with various doses of aluminum powder.

[Figura 5: Densidade aparente e absorção de água de compósito geopolimérico leve com adição de vários teores de pó de alumínio.] 
Strength results also showed that values of the formed green composite incorporating $0.0625 \%$ aluminum powder were much stronger than OPC cement according to ASTM C150 [45] where its standard strength values are 200 and $294 \mathrm{kgf} /$ $\mathrm{cm}^{2}$ at 7 and 28 days, respectively, whereas the produced lightweight product with the previously mentioned ratio was stronger in addition to its low production cost as most of the used materials are wastes, while cement uses virgin raw materials. It was recognized that lightweight concrete can be classified according to the purpose of its application as: i) structural lightweight concrete with cylinder compressive strength at 28 days equal or more than $17 \mathrm{MPa}$ and the approximate density range of $1400-1800 \mathrm{~kg} / \mathrm{m}^{3}$; ii) masonry concrete (structural/insulating lightweight concrete) with compressive strength between 7-14 MPa and density range of $500-800 \mathrm{~kg} / \mathrm{m}^{3}$; and iii) insulating concrete with compressive strength between $0.7-7 \mathrm{MPa}$ and density lower than $800 \mathrm{~kg} /$ $\mathrm{m}^{3}[46,47]$. So, the produced product can be used effectively in the production of high-strength lightweight concrete with strength values between 20 to $35 \mathrm{MPa}$. On the other hand, lightweight structural concrete is required under European standards having a density of less than $2000 \mathrm{~kg} / \mathrm{m}^{3}(2.0 \mathrm{~g} /$ $\mathrm{cm}^{3}$ ); most of the studied composites had density values $\leq 2.0 \mathrm{~g} / \mathrm{cm}^{3}$ at all curing ages which reflected the lightweight characteristics of composites.

Fig. 6a shows the typical microstructure of 90 days control geopolymer matrix free from aluminum powder; the matrix exhibited dense morphology with spreading unreacted kaolinite laminae in addition to geopolymer networks which come in accordance with kaolinite bands in FTIR spectrum. On adding $0.0625 \% \mathrm{Al}$ powder (Fig. $6 \mathrm{~b}$ ), an increased dissolution of kaolinite constituent was observed as shown by the matrix nearly free from kaolinite laminae which confirmed the seeding nucleation effect of added aluminum leading to modification of the resulted geopolymer by an increased intensity of its constituents, which was illustrated clearly from the cohesion of the formed matrix. Another role of the added aluminum to form lightweight composite was the releasing free hydrogen gas by alkaline interaction; this was confirmed by the micropores within the reacted particles. On increasing aluminum powder to $0.075 \%$ an increased liberation of hydrogen gas was noticed from the formation of large pores within the matrix, which adversely inhibited the interaction between formed geopolymer networks and so lowered its mechanical properties (Fig. 6c).

\section{Effect of aluminum slag}

On studying the effect of aluminum slag using FTIR for 28 days geopolymer composites incorporating various aluminum slag ratio up to $4 \%$ (Fig. 7), it was observed a marked decrease in the main asymmetric band (T-O-Si) with the addition of $1 \%$ aluminum slag as a result of alteration in the $\mathrm{Si} / \mathrm{Al}$ ratio, whilst there was a progressing increase in the asymmetric band with slight shifting to right by increasing aluminum slag to $3 \%$; the used slag resulted in modification of the geopolymer structure and formation of vitreous content [40], also shifted the band to lower wavenumber favoring the increase of amorphous gel phase as stated before [30]. On prolonged investigation, there was a growth in carbonate band with aluminum slag (3\%) which was considered beneficial in the formation of the cellular composite as compared with aluminum powder in spite of that the strength was lower. Increasing aluminum slag to $4 \%$ resulted in the increase of crystalline minerals associated with aluminum slag which adversely hindered geopolymerization reaction in addition to the adverse effect of hydrogen gas in increase porosity and so hinder the interaction between reacting particles as reflected on the decreased intensity of the main asymmetric band. The spectra clarified the fixed intensity of kaolinite bands beyond $3600 \mathrm{~cm}^{-1}$ which may be due to the lower efficiency of aluminum slag in enhancing geopolymerization reaction as compared with aluminum powder. There was an additional observation about carbonate bands at about 1440 and $870 \mathrm{~cm}^{-1}$; these bands decreased up on using $1 \%$ aluminum slag while increased with $3 \%$ and then had a sharp decrease with further increase in Alslag. This can be linked with the behavior of asymmetric

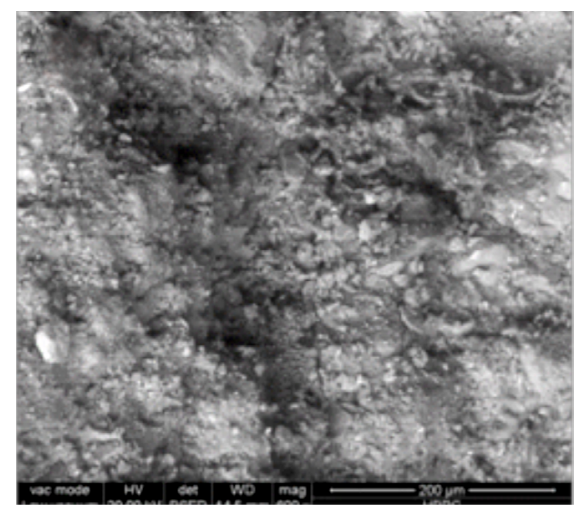

a)

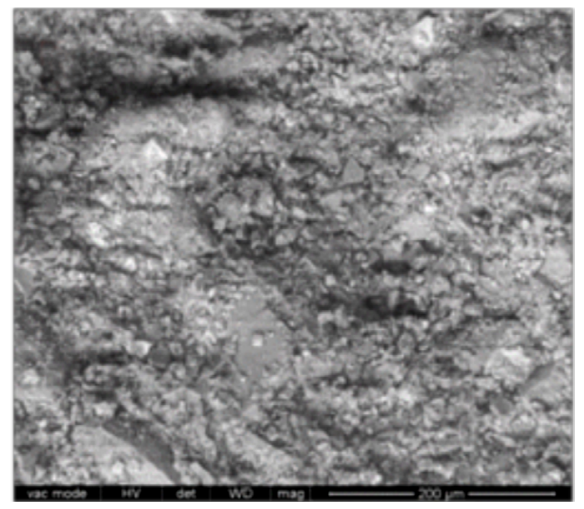

b)

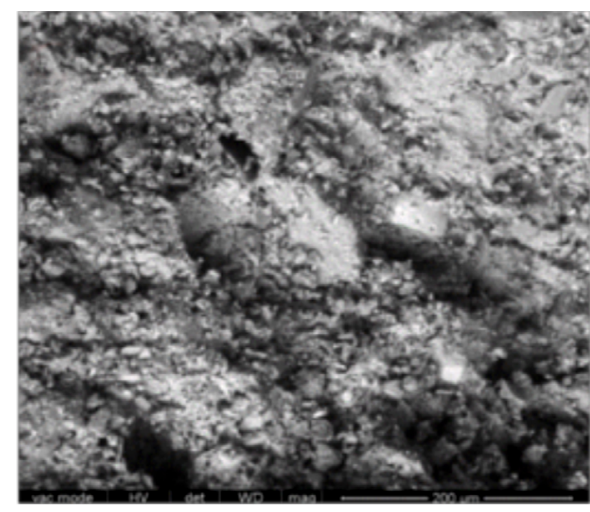

c)

Figure 6: SEM micrographs of 90 days lightweight geopolymer composite having various ratios of aluminum powder: a) $0 \%$; b) $0.0625 \%$; and c) $0.075 \%$.

[Figura 6: Micrografias de MEV do compósito geopolimérico leve aos 90 dias com vários teores de pó de alumínio: a) 0\%; b) 0,0625\%; e c) $0,075 \%$. 


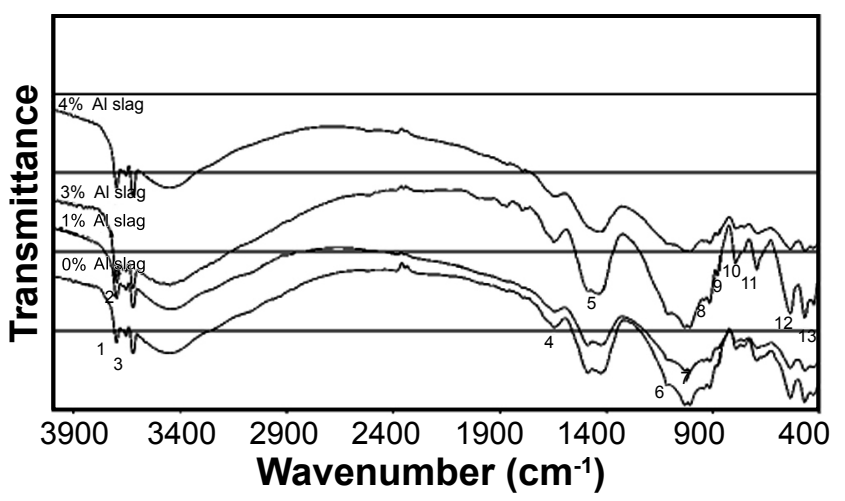

Figure 7: FTIR spectra of 28 days lightweight geopolymer composite having various ratios of aluminum slag. For the vibration modes indicated by the numbers, see the caption of Fig. 2 .

[Figura 7: Espectros de FTIR do compósito geopolimérico leve aos 28 dias com vários teores de escória de alumínio. Para os modos de vibração indicados pelos números, veja a legenda da Fig. 2.]

vibration of $\mathrm{T}-\mathrm{O}-\mathrm{Si}$ as the hydrogen gas which hindered interaction between the reacting particles led to lowering in carbonation rate of geopolymer composites with higher aluminum slag (4\%).

Fig. 8 shows XRD patterns of 28 days geopolymer composites incorporating various aluminum slag ratio; there was a similarity between these patterns and those for aluminum powder; a gradual increase in the amorphous geopolymer constituents with the increase of aluminum slag up to $3 \%$ was observed as well as an increased broadness in the range between $20-35^{\circ} 2 \theta$ for amorphous geopolymer constituents, while the main difference between them was an increased faujasite up on using higher aluminum powder ratio. However, this was not the case in aluminum slag mixes having a higher ratio (4\%) where no faujasite formed as the increased crystalline phases in slag constituents hindered the geopolymerization reaction and so lowered the

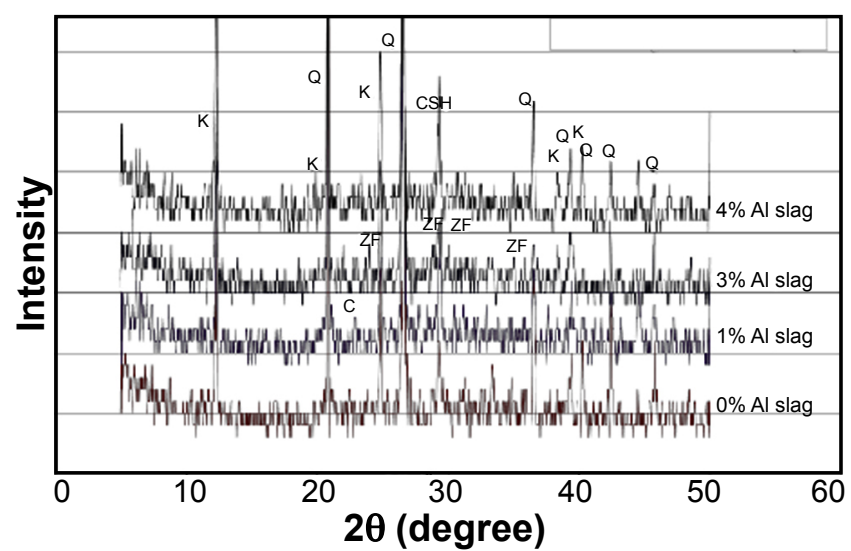

Figure 8: XRD patterns of 28 days lightweight geopolymer composite having various aluminum slag ratios: Q-quartz; K-kaolin; $\mathrm{CSH}$-calcium silicate hydrate; ZF-zeolite Na-F; C-calcite.

[Figura 8: Difratogramas de raios $X$ do compósito geopolimérico leve aos 28 dias com vários teores de escória de alumínio: $Q$-quartzo; K-caulim; CSH-silicato de cálcio hidratado; ZFzeólita $\mathrm{Na}-\mathrm{F}$; $\mathrm{C}$-calcita.] intensity of both asymmetric stretching as well as faujasite; this coincided with the low dissolution rate of the kaolinite constituent.

On investigating compressive strength, density and water absorption results for hardened geopolymer composite incorporated with various ratios of aluminum slag, cured up to 90 days (Figs. 9 and 10), there was an analogous behavior to that of aluminum powder where a gradual increase in strength with time as well as with aluminum slag up to $3 \%$ was observed, but still lower than that of control mix as a result of lower efficiency of aluminum slag in enhancing the geopolymerization reaction. First, strength decreased sharply upon using $1 \%$ slag precursor as a result of alteration of silica to alumina ratio, whereas strength increased with further aluminum slag up to $3 \%$ as illustrated in detail before about the efficiency of aluminum species in activating the reaction by seeding effect on nucleation, while the liberated gas can facilitate the formation of lightweight composites with lower density as compared with common building materials units. On further increase in aluminum slag to $4 \%$, strength decreased again as the intensity of zeolite $\mathrm{Na}-\mathrm{F}$ decreased which is known by its ability to enhance

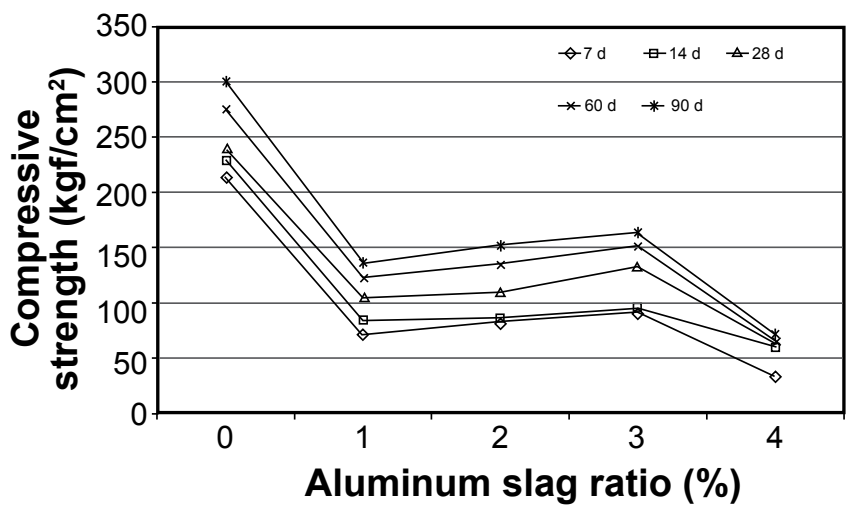

Figure 9: Compressive strength of lightweight geopolymer composite having various aluminum slag ratios, cured up to 90 days.

[Figura 9: Resistência à compressão do compósito geopolimérico leve com vários teores de escória de alumínio, curado até 90 dias.]

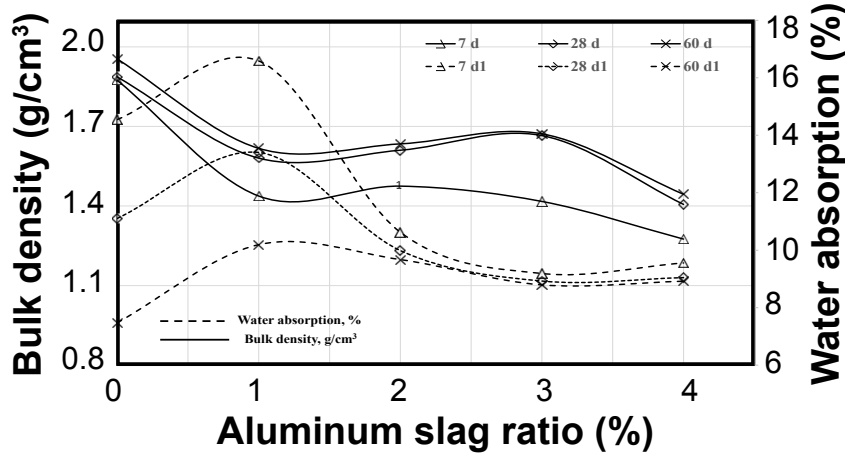

Figure 10: Bulk density and water absorption of lightweight geopolymer composite having various aluminum slag ratios.

[Figura 10: Densidade aparente e absorção de água de compósito geopolimérico leve com adição de vários teores de escória de alumínio.] 


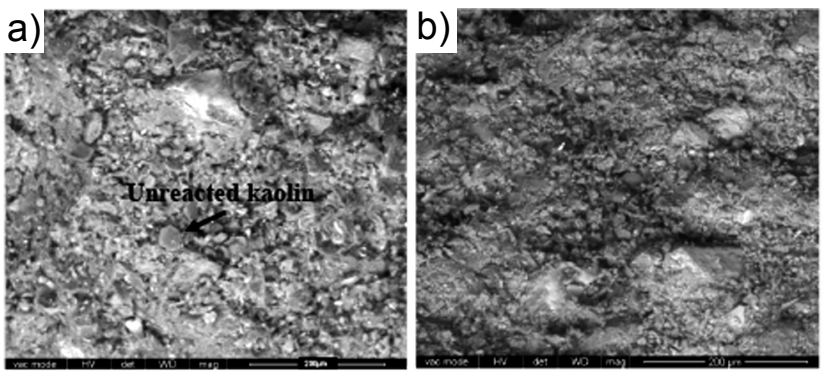

Figure 11: SEM micrographs of 90 days lightweight geopolymer composite doped with: a) $3 \% \mathrm{Al}$ slag; and b) $0.0625 \% \mathrm{Al}$ powder. [Figura 11: Micrografias de MEV de compósito geopolimérico leve aos 90 dias dopado com: a) 3\% de escória de Al; e b) 0,0625\% de pó de Al.]

the formed structure, in addition to decreased intensity of asymmetric geopolymer band in FTIR spectrum; the increased aluminum slag with its crystalline constituents hindered the formation of geopolymer chains as well as increased liberated gases decreasing the strength sharply by isolation of the interacting particles.

On comparing with strength values of aluminum powder specimens, lower strength values of Al-slag specimens were related to the lower reactivity of aluminum slag and its crystalline structure. The strength values were $214.0,91.2$ and $32.7 \mathrm{kgf} / \mathrm{cm}^{2}$ at 7 days and $239.5,133.0$ and $63.8 \mathrm{kgf} / \mathrm{cm}^{2}$ at 28 days for additions of 0,3 and $4 \%$ of aluminum slag, respectively, while the density values were $1.874,1.417$ and $1.275 \mathrm{~g} / \mathrm{cm}^{3}$ at 7 days and $1.886,1.665$ and $1.406 \mathrm{~g} / \mathrm{cm}^{3}$ at 28 days for the same ratios, whereas the absorption values were $14.54,9.19$ and $9.56 \%$ at 7 days and $11.10,8.93$ and $9.05 \%$ at 28 days as shown in Fig. 10 . An important conclusion is that the strength of the formed geopolymer composite incorporating $0.0625 \%$ aluminum powder was stronger than composites with aluminum slag, however from the point of view of lightweight principles, the density of the Al-slag specimens were lower than that of aluminum powder composites while the water absorption values were higher, which can be considered important from the point of view of lightweight composites as the density is lower by about one third. On classifying aluminum slag composites according to previously mentioned classification $[46,47]$, they can be suitable for masonry concrete (structural/ insulating lightweight concrete) with compressive strength between 7-14 $\mathrm{MPa}$ and density range of $500-800 \mathrm{~kg} / \mathrm{m}^{3}$, as well as insulating concrete with compressive strength between 0.7-7 MPa and density lower than $800 \mathrm{~kg} / \mathrm{m}^{3}$.

On comparing the morphology of cellular geopolymer composites incorporating aluminum powder and aluminum slag, a clear difference between their microstructures was observed where the $3 \%$ aluminum slag enhanced composite (Fig. 11a) showed low cohesion between their matrix as well as the spreading of unreacted kaolinite particles within its morphological structure, reflecting low enhancing ability of aluminum slag for activation and nucleation of geopolymer precursors as coincided with its low mechanical characteristics as compared with optimum aluminum powder enhanced geopolymer mix (Fig. 11b) which had dense structure with little evidence of unreacted kaolinite.

\section{CONCLUSIONS}

The paper investigated the incorporation of aluminum substituents as hydrogen gas emitting materials for reducing the density of the resultant geopolymer composites, while the raw materials for the base geopolymer mix were waste materials for lowering the production costs. There were some important findings that can be concluded from the present paper: 1) aluminum powder and aluminum slag can be used efficiently in the production of lightweight geopolymer materials resulting in low-density composites as compared with most common lightweight materials, where density of most cement concrete is 2.2 to $2.6 \mathrm{~g} / \mathrm{cm}^{3}$; 2) aluminum powder can be used up to $0.075 \%$ with acceptable properties and with density values $\leq 2.0 \mathrm{~g} / \mathrm{cm}^{3}$, which decreased with aluminum substituents increase, while addition of $0.0625 \%$ resulted in both high mechanical and morphological advantages with density in the same previous range whereas its 28 strength exceeded $350 \mathrm{kgf} / \mathrm{cm}^{2}$ which can be used effectively in the production of high-strength lightweight concrete; 3) aluminum slag can be used up to $4 \%$, while using $3 \%$ resulted in optimum mechanical characteristics with density lower than $1.70 \mathrm{~g} / \mathrm{cm}^{3} ; 4$ ) in spite of strength values of Al-slag specimens were lower than with aluminum powder, their density values were lower by about one third which encourages its beneficial use in lightweight material production.

\section{REFERENCES}

[1] S. Pinto, M. Almeida, A.M.S. Correia, J.A. Labrincha, V.M. Ferreira, K. Rosenbom, in: Proc. Int. RILEM Conf. Use Recyc. Mater. Build. Struct. 2 (2004) 771.

[2] M. Dondi, M. Marsigli, B. Fabbri, Tile Brick Int. 13, 4 (1997) 302.

[3] J.H. Tay, K.Y. Show, S.Y. Hong, Water Sci. Technol. 44, 10 (2001) 269.

[4] J. Davidovits, in: Geopolymer 2002 Conf., Melbourne (2002).

[5] J. Davidovits, J. Therm. Anal. 35 (1989) 425.

[6] T.W. Cheng, J.G. Chiu, Miner. Eng. 16 (2003) 205.

[7] K. Komnitsas, D. Zaharaki, Miner. Eng. 20 (2007) 1261.

[8] D. Khale, R. Chaudhary, Mater. Sci. 42 (2007) 729.

[9] P. Duxson, J. Van Deventer, in: Geopolymers, structure, processing, properties and applications, Eds. J. Provis, J. Van Deventer, Woodhead Publ., Cambridge (2009).

[10] M. Weil, K. Dombrowski, A. Buchawald, in: Geopolymers, structure, processing, properties and applications, Eds. J. Provis, J. Van Deventer, Woodhead Publ., Cambridge (2009).

[11] J. Liyana, H. Kamarudin, A.M. Mustafa Al Bakri, M. Binhussain, C.M. Ruzaidi, A.M. Izzat, Austr. J. Basic Appl. Sci. 7, 5 (2013) 182.

[12] R.E. Lyon, "Fire response of geopolymer structural composites", DOT/FAA/AR-TN95/22 (1996). 
[13] H.M. Khater, Adv. Cem. Res. 26, 1 (2014) 1.

[14] J. Davidovits, in: Proc. Int. Conf. Geopolymer, France (1999) 9.

[15] A.A. Omar, A.M. Mustafa Al Bakri, H. Kamarudin, I. Khairul Nizar, A.A. Saif, Constr. Build. Mater. 50 (2014) 377.

[16] H.S. Hassan, H.A. Abdel-Gawwad, S.R. Vásquez García, I.I. Alcántara, Waste Manage. 80 (2018) 235.

[17] R. Arellano Aguilar, O. Burciaga Diaz, J.I. Escalante Garcia, Constr. Build. Mater. 24 (2010) 1166.

[18] A.M. Neville, in: Properties of concrete, John Wiley \& Sons, UK (1995) 688.

[19] E.A. Azimi, M.M. Al Bakri Abdullah, L.Y. Ming, H.C. Yong, K. Hussin, I. Hakem Aziz, Rev. Adv. Mater. Sci. 44 (2016) 273.

[20] G. Roviello, C. Menna, O. Tarallo, L. Ricciotti, F. Messina, C. Ferone, D. Asprone, R. Cioffi, Composites Part B 128 (2017) 225.

[21] D.L. Bean, P.G. Malore, "Alkali-activated glassy silicate foamed concrete", US patent 5,605,570A (1997).

[22] C. Vargel, in: Corrosion of aluminium, Ed. C. Vargel, Elsevier Sci., UK (2004) 385.

[23] O. Hollins, "Aluminium industry could dramatically reduce landfilling of furnace" (2002) http://www.ohlsti. co.uk/ohl/newsletter/ohl_wmr312.pdf, acc. 11.11.2007.

[24] M. Brough, "Aluminium lightens the environmental load" (2002) http://www.berr.gov.uk/files/file30193.pdf, acc. 11.11.2007.

[25] F. Puertas, M.T. Blanco-Varela, T. Vazquez, Cem. Concr. Res. 29 (1999) 1673.

[26] D.A. Pereira, B. Aguiar, F. Castro, M.F. Almeida, J.A. Labrincha, Cem. Concr. Res. 30 (2000) 1131.

[27] H.M. Khater, Green Mater. J. 1, 1 (2013) 36.

[28] H.A. El-Sayed, S.A. Abo El-Enein, H.M. Khater, S.A. Hasanein, Ceramics - Silikáty 55, 2 (2011) 153.

[29] ASTM C109M, "Standard test method for compressive strength of hydraulic cement mortars" (2016).
[30] D. Panias, L.P. Giannopolou, T. Peraki, Colloids Surf. A 301 (2007) 246.

[31] T. Bakarev, Cem. Concr. Res. 36 (2006) 1134.

[32] ASTM C140, "Standard test methods for sampling and testing concrete masonry units and related units" (2016).

[33] Egyptian Stand., "Concrete building units used in non load and load bearing walls", 1292-2 (2015).

[34] B.I. Ugheoke, E.O. Onche, O.N. Namessan, G.A. Asikpo, Leonardo Electron. J. Pract. Technol. 9 (2006) 167.

[35] T. Bakharev, Cem. Concr. Res. 35 (2005) 1233.

[36] A. Palomo, M.W. Grutzeck, M.T. Blanco, Cem. Concr. Res. 29 (1999) 1323.

[37] A.S. Vargas, D.C.C. Dal Molin, Â.B. Masuero, A.C.F. Vilela, J. Castro-Gomes, R.M. Gutierrez, Cem. Concr. Compos. 53 (2014) 341.

[38] H.M. Khater, A.M. El Nagar, M. Ezzat, J. Chem. Mater. Res. 8, 1 (2016) 21.

[39] S.A. Bernal, J.L. Provis, V. Rose, R.M. Gutierrez, Cem. Concr. Compos. 33 (2011) 46.

[40] C.A. Rees, J.L. Provis, G.C. Lukey, J.S.J. van Deventer, Colloids Surf. A 318 (2008) 97.

[41] J. Temuujin, A. van Riessen, R. Williams, J. Hazard. Mater. 167, 1-3 (2009) 82.

[42] R.M. Barrer, D.E. Mainwaring, J. Chem. Soc. Dalton Trans. O (1972) 2534.

[43] J.L. Provis, G.C. Lukey, J.S.J. van Deventer, Chem. Mater. 17 (2005) 3075.

[44] Z. Zuhua, Y. Xiao, C. Yeu, Appl. Clay Sci. 43 (2009) 218.

[45] ASTM C150, "Standard specification for Portland cement" (2016).

[46] A.M. Neville, J.J. Brooks, Concrete technology, $2^{\text {nd }}$ ed., Prentice Hall (2010).

[47] A.A. Slaby, K.I. Aziz, A.F. Hadeed, Iraqi J. Civil Eng. 10, 10 (2008) 1.

(Rec.22/07/2018, Rev.26/09/2018, 16/10/2018, 30/10/2018, Ac. 31/10/2018) 